\title{
Study on Japan's Seamless Aid Mechanism of Overseas Mineral Resources Exploration and Development
}

\author{
JIANG Ya \\ College of Geoscience \& Surveying Engineering \\ China University of Mining and Technology (Beijing) \\ Information center of Ministry of Land and Resource \\ Beijing, P. R. China \\ yjiang@infomail.mlr.gov.cn \\ ZHAO Feng-hua \\ College of Geoscience \& Surveying Engineering \\ China University of Mining and Technology（Beijing） \\ Beijing, P. R. China \\ zfh@cumtb.edu.cn
}

\begin{abstract}
This paper's objective is to solve the problem of China's Oversea Mineral Resources Exploration and Development. Based on the similarities and fundamental differences between Japan and China, we analyzed the experience of Japan's useful ideas, and we also compared and analyzed the strategic configuration of our country's mineral going-out strategy with several ministries and organizations. The results show that Japan's global resource cycle system is a two-dimensional seamless-aid mechanism model, which brings them more benefits about mineral resources security. From this we can draw a conclusion that we need to pay more attention on Japan's useful experiences, to realize the win-win mechanism of national strategies and enterprise business combination.
\end{abstract}

Keywords-Public Administration; Management Mechanism; Seamless aid system; Overseas Mineral Resources;Japan-mode

\section{INTRODUCTION}

In May, 2006, the Japanese government introduced the "Integrated Resource Protection Strategy".They proposed a law to develop guidelines to ensure a safe and stable supply of resources. The government and relevant departments should be in accordance with the requirements of the guide to jointly secure the resources. The proposed guideline defined that the government and the new financial institution take the commitment of resources financial services, and provide assistance for Japanese mining companies accessing to overseas mineral resources development interests.

The specific main implementation for assistance work is undertaken by Japan Oil, Gas and Metals National Corporation (JOGMEC), Japan Bank for International Cooperation (JBIC), Nippon Export and Investment Insurance (NEXI), and Japan International Cooperation Agency (JICA). They complement each other by implementing seamless assistance to overseas mineral resources development company throughout the life cycle of mining operations, from the grassroots exploration to detailed geological surveys, tax concessions, mining, metal smelting, slag recycling technology development,

\author{
$\mathrm{LI} \mathrm{Fu}$ \\ School of International Studies \\ RENMIN University \\ Beijing, P. R. China \\ lifuly@vip.sina.com
}

\author{
ZHANG Shuai \\ College of Geoscience \& Surveying Engineering \\ China University of Mining and Technology (Beijing) \\ Beijing, P. R. China \\ szhang870119@hotmail.com
}

investment and financing, grant applications, debt guarantees, mine production technology and the training of personnel.

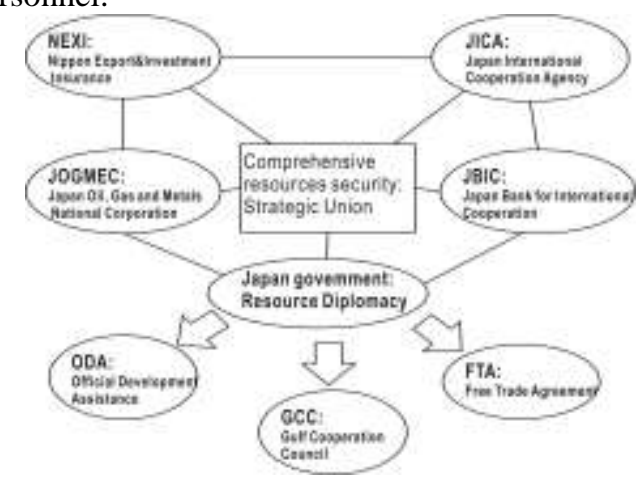

Figure1. The relationship between each of the Japanese comprehensive resource development Organizations

Among them, the JOGMEC is mainly responsible for the geological surveys, financing, debt guarantees, etc., JBIC for financing and debt guarantee, NEXI for trade insurance, and JICA for development of the surveys, staff training, organizational training classes, dispatch of experts, cooperation standard surveys and loans and so on. It is due to the combined operations of the four agencies, which makes Japanese overseas exploration and development of mineral resources management system smoothly progress, and ultimately form "one-step" service for a seamless management system. Therefore, these four organizations constitute the four pillars for the seamless management system development of Japan's overseas exploration and development of mineral resources, as shown in Fig .1.

\section{ORGANISATIONS OF THE 7 STAGES OF JAPAN'S OVERSEAS MINERAL RESOURCES EXPLORATION}

Japan divides the entire process of abroad mineral resources prospecting and exploitation into seven stages. Among them, 14 institutions mutually interact to 
TABLE I. The 14 AID-SEAMLESS ORgANS ON THE 7 StAgES OF JAPAN’S OVERSEAS MineRAL RESOURCES EXPLORATION

\begin{tabular}{|c|c|c|c|c|c|c|c|}
\hline 14 Aid Organizations 7 Stages & $\begin{array}{l}\text { Grassroots } \\
\text { Exploration }\end{array}$ & $\begin{array}{l}\text { Detailed } \\
\text { Exploration }\end{array}$ & $\begin{array}{l}\text { Surrounding } \\
\text { Construction } \\
\text { Survey }\end{array}$ & $\begin{array}{l}\text { Mine } \\
\text { Developm } \\
\text { ent }\end{array}$ & $\begin{array}{l}\text { Mining } \\
\text { Processing }\end{array}$ & $\begin{array}{l}\text { Mining } \\
\text { \&Industry } \\
\text { Cooperation }\end{array}$ & $\begin{array}{l}\text { Resource } \\
\text { Diplomacy }\end{array}$ \\
\hline $\begin{array}{l}\text { 1. METI Bureau of Nonferrous Metal } \\
\text { Manufacturing Industry Division }\end{array}$ & & & & & & • & \\
\hline $\begin{array}{l}\text { 2. METI Industrial Science and Technology } \\
\text { Environment Agency Recycling Promotion } \\
\text { Division }\end{array}$ & & & & & & $\bullet$ & \\
\hline $\begin{array}{l}\text { 3. METI Economic Cooperation Bureau of } \\
\text { Technical Cooperation Division }\end{array}$ & & & $\bullet$ & & & & $\bullet$ \\
\hline $\begin{array}{l}\text { 4. ETI Economic and Trade Cooperation } \\
\text { Bureau, Financial Cooperation Lesson }\end{array}$ & & & $\bullet$ & & & & \\
\hline $\begin{array}{l}\text { 5. METI Economic Cooperation Bureau of } \\
\text { Trade Insurance Division }\end{array}$ & & $\bullet$ & $\bullet$ & $\bullet$ & $\bullet$ & & \\
\hline $\begin{array}{l}\text { 6. METI Resources and Energy Agency of } \\
\text { Mineral Resources Division }\end{array}$ & $\bullet$ & $\bullet$ & & $\bullet$ & $\bullet$ & $\bullet$ & \\
\hline $\begin{array}{l}\text { 7. METI Resources and Energy Resources } \\
\text { Division, Nuclear Fuel Gas Electricity Policy } \\
\text { Division }\end{array}$ & & & & & & $\bullet$ & \\
\hline $\begin{array}{l}\text { 8. METI Resources and Energy Resources } \\
\text { Division of Nuclear Fuel for Electricity, Gas } \\
\text { Fuel Cycle Industry Section }\end{array}$ & & & & & & $\bullet$ & \\
\hline $\begin{array}{l}\text { 9. METI Department of Energy } \\
\text { Conversation and New Energy, Resources } \\
\text { and Energy Office }\end{array}$ & & & & & & $\bullet$ & \\
\hline 10. JOGMEC & $\bullet$ & $\bullet$ & & $\bullet$ & $\bullet$ & & \\
\hline 11. JBIC & & $\bullet$ & $\bullet$ & $\bullet$ & $\bullet$ & & \\
\hline 12. JICA & & & - & & & & $\bullet$ \\
\hline 13. NEXI & & $\bullet$ & $\bullet$ & $\bullet$ & $\bullet$ & & \\
\hline $\begin{array}{l}\text { 14. AIST Geological Survey Comprehensive } \\
\text { Center }\end{array}$ & • & & & & & & \\
\hline
\end{tabular}

TAble II. The 19 Aid-Operating Mechanisms on the 7 StAgEs of JaPAN’s Global Mineral Resources Exploration

\begin{tabular}{|c|c|c|c|c|c|c|c|}
\hline 19 Aid Operations 7 Stages & $\begin{array}{l}\text { Grassroots } \\
\text { Exploration }\end{array}$ & $\begin{array}{l}\text { Detailed } \\
\text { Exploration }\end{array}$ & $\begin{array}{l}\text { Surrounding } \\
\text { Construction } \\
\text { Surveys }\end{array}$ & $\begin{array}{l}\text { Mine } \\
\text { Development }\end{array}$ & $\begin{array}{l}\text { Mining } \\
\text { Processing }\end{array}$ & $\begin{array}{l}\text { Mining } \\
\text { \&Industry } \\
\text { Cooperation }\end{array}$ & $\begin{array}{l}\text { Resource } \\
\text { Diplomacy }\end{array}$ \\
\hline 1 Preliminary Joint Exploration of Risks & $\star$ & & & & & & \\
\hline 2 Overseas Geological Surveys & & $\star$ & & & & & \\
\hline $\begin{array}{l}3 \text { Outside Grants of the United Geological } \\
\text { Survey }\end{array}$ & & $\bullet$ & & & & & \\
\hline $\begin{array}{l}4 \text { Circumstances Investigation Surrounding the } \\
\text { Mine }\end{array}$ & & & $\star$ & & & $\star$ & \\
\hline 5 Financing of Exploration & & $\bullet$ & & & & & \\
\hline 6 Equity Acquisition Financing & & $\bullet$ & & & & & \\
\hline 7 Minerals Import \& Trade Financing & & $\bullet$ & $\bullet$ & $\bullet$ & $\bullet$ & & \\
\hline $\begin{array}{l}8 \text { Government Direct Funding (up to } 25 \% \\
\text { Equity) }\end{array}$ & & $\bullet$ & $\bullet$ & $\bullet$ & $\bullet$ & & \\
\hline 9 Financing to Help Foreign Companies & & & & & $\bullet$ & & \\
\hline 10 Guarantee for Private Debt & & & & $\bullet$ & & & \\
\hline 11 Reinsurance of Overseas Investment Loss & & $\circ$ & $\circ$ & $\circ$ & $\circ$ & & \\
\hline 12 Reinsurance of Foreign Political Risk & & $\circ$ & $\circ$ & $\circ$ & $\circ$ & & \\
\hline $\begin{array}{l}13 \text { Overseas Exploration Risk Reserve } \\
\text { (Regulation of Corporate Behavior) }\end{array}$ & & $\Delta$ & & $\Delta$ & $\Delta$ & & \\
\hline $\begin{array}{l}14 \text { Feasibility Investigation of Rare Metals } \\
\text { Smelting }\end{array}$ & & $\star$ & & & & & \\
\hline 15 Mining Technical Assistance & & $\star$ & & & $\star$ & & \\
\hline $\begin{array}{ccc}\text { JICA: Provide Geological Technical } \\
\text { Assistance to Resources Country }\end{array}$ & & & $\star$ & & & $\star$ & $\star$ \\
\hline $\begin{array}{l}17 \text { JICA: Geological Personnel Training for } \\
\text { Resources Country }\end{array}$ & & & & & & $\star$ & $\star$ \\
\hline $\begin{array}{l}18 \text { JICA: Technical Cooperation } \\
\text { Resources Country (Sending Experts) }\end{array}$ & & & & & & $\star$ & $\star$ \\
\hline $\begin{array}{l}\text { Overseas Investment Loss Reserve } \\
\text { (Regulation of Corporate } \\
\text { Behavior) }\end{array}$ & & $\Delta$ & & $\Delta$ & $\Delta$ & & \\
\hline
\end{tabular}


seamlessly combine the 19 overseas mining development assistance. The roles of 14 institutions in the seven stages of mining development are shown in table 1 .

There are 19 aid measures which can be divided into five kinds of assistance and class specifications. Their distribution in Japan outside of the seven stages of mining development is shown in table 2 .

\section{JAPANESE SEAMLESS IMPLEMENTATION OF PROCESS AID MECHANISM}

The first stage is the most difficult stage during the development of overseas mining activities in exploration. The main institute is JOGMEC, who plays a role involved in the exploration, financing, technical aspects. They are not only responsible for screening the payment of exploration grants, they are also responsible for Japan's strategic resources and ore reserves of harm prevention work. They are the brand agency of Japanese overseas mining industry.

The second phase is the detailed investigation stage. After the introduction of the Japanese prospect delineation of mining companies, the government funding drops from $100 \%$ up to $50 \%$, this will be reduced to one-third if no mine is found within four years. If a mine is found, the corporation proportionally submits profits to the government. Grants, reserves, reinsurance system are also involved in the detailed investigation stage.

The second important institution is JBIC who provides the funds, whose status is comparable to the China's Export-Import Bank and the National Development Bank. It is the Japan's state-owned policy bank, and the main channel for financing Nippon Mining and the most powerful financial backing. JICA is mainly responsible for the training of the country's human resources, dispatch of experts to countries with resources, and providing them with advanced technology. They also dominate the sixth stage (industrial cooperation between the two countries) and seventh stage (resource diplomacy between the two phases). JICA is in the intermediate four links including detailed investigation, infrastructure, development, mining and processing, and is primarily

\section{China's Overseas Mineral Resources DEVELOPMENT MANAGEMENT SYSTEM AND OPERATIONAL MECHANISM}

At present, China's multi organizations linkage mechanism of overseas mineral resources exploration and development has been basically formed. Its characteristics are: Macro strategy, information guidance, geological prospecting in advance, following up the enterprises; escorting the financial and insurance, building the platform, training talent; technical cooperation and mining industry cooperation. Although China has its own ways to drive her overseas mineral responsible for assisting the private financing of "reinsurance" program. The sequence of the four institutes of overseas mining development departments in Japan's seven stages of "going out" are shown in Fig .2:

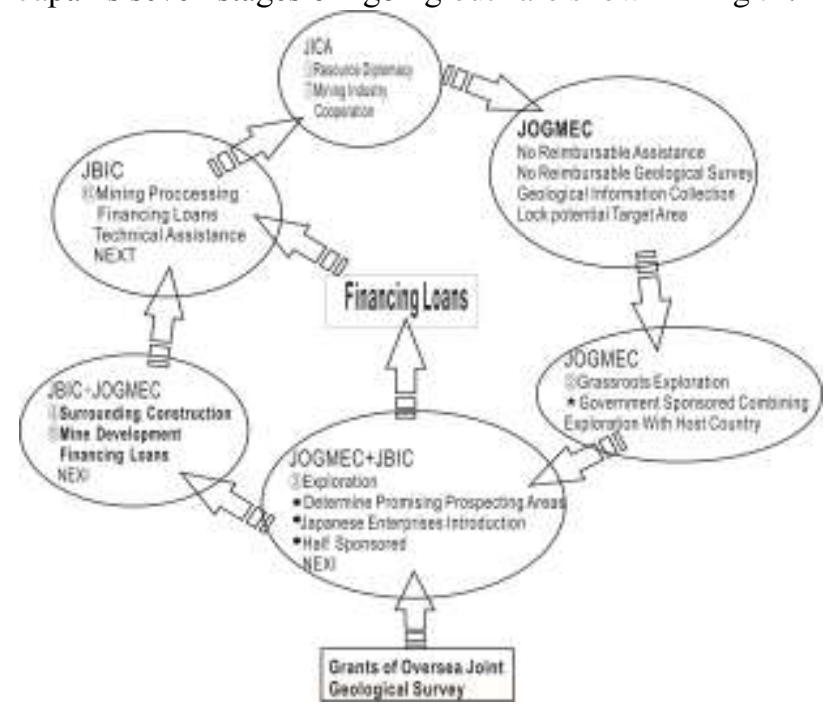

Figure 2. The Sequence of Seamless Aid Operating Mechanisms of Japan's Global Mineral Resources Exploration

Deposits must be submitted to the Japanese government before going out and after mining ore deposit projects. Firstly, it is in order to help private financing, secondly, is to regulate corporate behavior abroad with the purpose of preventing speculation tenements or bad business practices. Exploration risk deposits are the half of ore mining business earnings in the first year, and given out over three years. Investment loss deposit is submitted before corporation going out, the amount of which depends on the risk of the project. If the investment is the exploration project, then $50 \%$ of the total amount of investment must be kept within Japan, that is, if you have 20 million, can only take out 10 million, there is 10 million going to be kept within the country as a deposit, so that the Bank of Japan can reassure gvie such loans to private enterprises.

resources exploration and development, it still has a lot of problems that need to be solved urgently. Therefore, Japan's 60 years of development experience and unique operation model can give us very good enlightenment.

In order to make a comparative study of oversea mineral resources exploration between China and Japan, we have divided the entire process of overseas mineral resources prospecting and exploitation into seven stages. Among them, there are 15 institutions involved. The roles of the 15 institutions in the seven stages of overseas mining exploration and development are shown in table 3. 
TABLE III. AID-SEAMLESS ORGANS ON THE 7 STAGES OF CHINA's OVERSEAS Mineral RESOURCES EXPLORATION

\begin{tabular}{|c|c|c|c|c|c|c|c|c|c|}
\hline \multicolumn{2}{|c|}{15 Aid Organs } & Approve & $\begin{array}{l}\text { Grassroots } \\
\text { Exploration }\end{array}$ & $\begin{array}{c}\text { Detailed } \\
\text { Exploration }\end{array}$ & $\begin{array}{l}\text { Surrounding } \\
\text { Construction } \\
\text { Surveys }\end{array}$ & $\begin{array}{c}\text { Mine } \\
\text { Development }\end{array}$ & $\begin{array}{c}\text { Mining } \\
\text { Processing }\end{array}$ & $\begin{array}{l}\text { Mining } \\
\text { \&Industry } \\
\text { Cooperation }\end{array}$ & $\begin{array}{l}\text { Resource } \\
\text { Diplomacy }\end{array}$ \\
\hline 1 & $\mathrm{MC}$ & $\bullet$ & & & & & $\bullet$ & & $\bullet$ \\
\hline 2 & NDRC & $\bullet$ & & & & $\bullet$ & $\bullet$ & & $\bullet$ \\
\hline 3 & MF & & $\bullet$ & $\bullet$ & $\bullet$ & $\bullet$ & & & \\
\hline 4 & MLR & & $\bullet$ & $\bullet$ & $\bullet$ & $\bullet$ & $\bullet$ & & $\bullet$ \\
\hline 5 & MFA & & & & & & & - & $\bullet$ \\
\hline 6 & MIIT & & & & & $\bullet$ & $\bullet$ & & $\bullet$ \\
\hline 7 & MST & & & & & & $\bullet$ & & \\
\hline 8 & SAFE & $\bullet$ & & & & & & & $\bullet$ \\
\hline 9 & GAC & $\bullet$ & & & & & & & $\bullet$ \\
\hline 10 & SAT & $\bullet$ & & & & & & & $\bullet$ \\
\hline 11 & CCPIT & & & & & $\bullet$ & $\bullet$ & & $\bullet$ \\
\hline 12 & ACFIC & & & & & $\bullet$ & $\bullet$ & & $\bullet$ \\
\hline 13 & CDB & & & $\bullet$ & $\bullet$ & $\bullet$ & $\bullet$ & & \\
\hline 14 & EIBC & & & $\bullet$ & $\bullet$ & $\bullet$ & $\bullet$ & & \\
\hline 15 & CECIC & & & $\bullet$ & $\bullet$ & $\bullet$ & $\bullet$ & & \\
\hline
\end{tabular}

There are 19 aid measures which can be divided into five kinds of assistance and one class specification. Their mineral resources exploration and development is shown distribution in the seven stages of China's overseas in table 4.

Table IV. The Aid-OPerating Mechanisms on the 7 Stages of China's Global Mineral Resources Exploration

\begin{tabular}{|c|c|c|c|c|c|c|c|c|}
\hline $\begin{array}{ll}\text { Dimension 2: } \\
\text { Aid Operatings }\end{array}$ & $\begin{array}{l}\text { G. } \\
\text { Explo } \\
\text { ration }\end{array}$ & $\begin{array}{l}\text { D. } \\
\text { Explor } \\
\text { ation }\end{array}$ & $\begin{array}{l}\text { S.C. } \\
\text { Survey }\end{array}$ & $\begin{array}{c}\text { Mine } \\
\text { Develo } \\
\text { pment }\end{array}$ & $\begin{array}{c}\text { Mining } \\
\text { Process } \\
\text { ing }\end{array}$ & $\begin{array}{l}\text { Mining } \\
\text { Cooper } \\
\text { ation }\end{array}$ & $\begin{array}{l}\text { Resource } \\
\text { Diplomacy }\end{array}$ & $\mathrm{Din}_{\mathrm{Aid}}$ \\
\hline 1 Preliminary Joint Exploration of Risks & $\star$ & & & & & & & MLR、MC \\
\hline 2 Overseas Geological Surveys & & $\star$ & & & & & & MLR、MC \\
\hline $\begin{array}{l}3 \text { Outside the United Geological Survey } \\
\text { Grants }\end{array}$ & & - & & & & & & CGEFMLR \\
\hline 4 Surrounding the Mine Investigation & & & $\star$ & & & $\star$ & & CGSMLR \\
\hline 5 Financing of Exploration & & $\bullet$ & & & & & & MF \\
\hline 6 Equity Acquisition financing & & $\bullet$ & & & & & & CDB、EIBC \\
\hline 7 Minerals Import \& Trade Financing & & $\bullet$ & - & - & - & & & CCPIT、EIBC \\
\hline 8 Direct Government Funding & & $\bullet$ & $\bullet$ & $\bullet$ & $\bullet$ & & & MF、CDB \\
\hline 9 Financing to Help Foreign Companies & & & & & $\bullet$ & & & CDB、 EIBC \\
\hline 10 For $\quad$ Private Debt Guarantee & & & & $\star$ & & & & CDB、EIBC \\
\hline 11 Overseas Investment Loss Reinsurance & & $\circ$ & o & $\circ$ & o & & & CECIC \\
\hline 12 Foreign Political Risk Reinsurance & & 0 & 0 & 0 & 0 & & & CECIC \\
\hline 13 Offshore Exploration Risk Reserve & & $\Delta$ & & $\Delta$ & $\Delta$ & & & $\mathrm{CDB}$ \\
\hline $\begin{array}{l}14 \text { Investigate the Feasibility of Rare } \\
\text { Metals Smelting }\end{array}$ & & $\star$ & & & & & & MST、CAGSMLR \\
\hline 15 Mining $\quad$ Technical $\quad$ Assistance & & $\star$ & & & $\star$ & & & CGSMLR、CAGSMLR \\
\hline 16 Provide Geological Technical Assistance & & & & & & $\star$ & $\star$ & CGSMLR、CAGSMLR \\
\hline 17 Geological Personnel Training & & & & & & $\star$ & $\star$ & CGSMLR、CMAMLR \\
\hline 18 Technical Cooperation & & & & & & $\star$ & $\star$ & CGSMLR、CMAMLR \\
\hline 19 Overseas Investment Loss Reserve & & $\Delta$ & & $\Delta$ & $\Delta$ & & & CGEFMLR \\
\hline
\end{tabular}

\section{V.RESULTS}

We did a comparative study on the overseas mining development of the seven stages of the aid system between China and Japan. The result showed that the first problem faced by China's mining enterprise "going out" is where to get the minerals. However, Japan locks the resource potential target in the diplomatic stage, and sends the first-hand data back to Japan for analysis during the foreign aid geological survey. In other words, in the first stage, they have made a layout for the seventh stage, beginning to end, so Japan is following a cycle.

In the first exploration stage, Japan government's funding is $100 \%$. With the funds, JOGMEC and Resources Company or Japanese subsidiaries in the resources country jointly carry out the geological surveys. Currently, China does not supply $100 \%$ of the funds in the grassroots exploration, and we do not give much support for financing of private enterprises entering this stage.

The role of grant is equivalent to the China Geological Exploration Fund, but the China Geological Exploration Fund is unpaid for abroad but paid for domestically. Japan's domestic and foreign grants are paid to use, once the company find a mine, the government will share its profits, which would also contribute to the grants cycle through sustainable use.

After detailed investigation of the mine, then it is the investigation stage of setting up and improving the foundation around the mine. From the beginning of this stage, the JBIC takes over JOGMEC and begins to play a dominant role. It is essential to investigate the infrastructure surrounding the mine before mine exploration. Japan treats this stage as a single exploration stage showing its importance. By comparison, our country lacks in this regard, there are cases related to that the exploration right was bought by other countries 
because of the lack of fresh water and traffic surrounding the mine area.

\section{CONCLUSIONS}

\section{A. The Macro View}

At present, Chinese enterprises investing in overseas mining meet many problems in the approval procedures, mainly due to the contradictory of relevant decisions and business-related overlaps caused by the dispersion of approving authorities. Also, a serious waste of resources makes the country unable to implement a global strategic layout for mineral resources from a global perspective. Therefore, it should improve the efficiency and hand over the energy, mineral resources, planning and reserve to the land and resources departments to centrally manage. It should let land and resources departments play a more important role in the approval of mining projects in overseas.

\section{B. The Meso View}

China should establish an organization similar to JOGMEC, which can stand between investors and mining rights or mining projects and stand between governments and businesses acting as a more professional and refined brand of intermediary service agencies to address the problem of asymmetric information. Seven stages of mining development is a chain of organic whole. Once the asymmetry information is resolved, the financing problem will also be solved.

\section{The Micro View}

At present, China's mining enterprises "going out" is facing intense pressure from the country's new resource nationalism. We can refer to the method that the micro-business subjects lead the charge, the intermediary agencies coordinate, and government administrates behind the scenes guide the private and state-owned enterprises to make use of their advantages for a reasonable division of labor in the different stages of exploration and development, and fully mobilize the enterprises initiative to achieve overall prosperity for foreign mining investment.

\section{REFERENCES}

[1] D. Wang, et al. Seamless Government: Public Sector Recycling Guidelines. Beijing: China Renmin University Press, 2002,pp.80-82.

[2] METI. Japan's Mineral Resources security Strategy [EB $\backslash \mathrm{OL}$ ] (2009-8-11)[2014-3-2].http://www.meti.go.jp/sekiyu_gas/01-html - [accessed 2nd March 2014]

[3] METI.Bureau of Energy and Mineral Resources.Japan's oil,gas and mineral Resources Polisy[EB/OL].(2006-11-8)[2014-9-15]. http://www.enecho.meti.go.jp/category/resources_and_fuel/strateg y/ Mining [accessed 2nd March 2014]

[4] L.P. Chen, W. Wang, Y. Jiang. Can Global Mining Reshuffle[N] China Land and Resources and Mineral Week.Apr.2009

[5] F. Zhu. Chinas Ascent: Power, Security and the Future of International Politics.Ithaca: Cornell University Press,2008.pp.52-53.

[6] Historical Statistics for Mineral and Material Commodities in Japan. U.S. Geological Survey(Aug.2012)[May.2014] http://www.mineral..usgs.gov/ds/2012/18 [accessed 2nd March 2014]

[7] Y Peng, D.Jun, W.A. Jian,et al. "Analysis of Japan's oversea resource acquisition mechanism," Acta Geoscientica Sinica, vol 31, No 5, pp.711-719, Oct.2010.

[8] L.H. Xia. Analysis on Japan's Mineral Investment AfterWar[D].Jilin: Jilin University.Apr.2010.pp.20-23.

[9] Y. Jiang. Study on Japan's Seamless Mechanism system on Oversea Mineral Resources Exploration and Development[D].Beijing: University of Science and Technology Beijing, Jun.2011.pp.12-24.

[10]A.J.Wang, G.S.Wang, J.H.Zhang, et al. "The Mineral Resources Demand Theory and the Prediction Model," Acta Geoscientica Sinica, vol 31, No 2, pp.137-147,Jul. 2010. 